\title{
Contamination of pine and birch wood dust with microscopic fungi and determination of its sterol contents
}

\author{
Kinga Stuper-Szablewska ${ }^{1}$, Tomasz Rogoziński², and Juliusz Perkowski ${ }^{1}$ \\ Department of Chemistryl, Department of Furniture Design'2, Poznan University of Life Sciences, Poznań, Poland
}

[Received in December 2016; Similarity Check in December 2016; Accepted in May 2017]

\begin{abstract}
Wood compounds, especially sterols, are connected with the level of contamination with microscopic fungi. Within this study, tests were conducted on wood dust samples collected at various work stations in a pine and birch timber conversion plant. Their contamination with mycobiota was measured as the concentration of ergosterol (ERG) by ultra performance liquid chromatography (UPLC). Another aim of this study was to assess the effect of contamination with microscopic fungi on the sterol contents in wood dusts. Analyses were conducted on five sterols: desmosterol, cholesterol, lanosterol, stigmasterol, and $\beta$-sitosterol using UPLC and their presence was confirmed using gas chromatography/mass spectrometry (GC/MS). The results of chemical analyses showed the greatest contamination with mycobiota in birch wood dust. We also observed varied contents of individual sterols depending on the wood dust type. Their highest concentration was detected in birch dust. The discriminant analysis covering all tested compounds as predictors showed complete separation of all tested wood dust types. The greatest discriminatory power was found for stigmasterol, desmosterol, and ergosterol.
\end{abstract}

KEY WORDS: ergosterol; gas chromatography; mycobiota; woodworking

Pine and birch wood used as raw materials vary in terms of their properties. Apart from their provenance, structure, physical properties, and chemical composition they also differ in their resistance to biological agents, which is one of the factors determining wood durability. Resin-soaked pine wood with distinct heartwood exhibits much lesser susceptibility to fungal infection in contrast to birch wood, devoid of heartwood and free from these substances. Apart from the barrier to fungal infection, provided by a high resin content in wood, a greater lignin content in softwood protects it against fungal growth more effectively, since lignin protects the carbohydrate components of wood structure. A considerable effect on wood durability is also played by additives, i.e. tannins, gums, resin compounds, proteins, sugars, vitamins, and sterols (1). During vegetation, living trees secrete resin hence protecting their xylem against fungi and insects. After felling, this process stops, opening up a possibility for a secondary wood contamination with microscopic fungi.

Decay during fungal infection requires four basic conditions to develop and these have to be met simultaneously: timber as a source of food, oxygen, water, and adequate temperature. All of these basic requirements are found in forests and woodworking plants. Using wood as a source of food, fungi degrade individual wood components, primarily cellulose, releasing in this process

Correspondence to: Tomasz Rogoziński, Department of Furniture Design, Faculty of Wood Technology, Poznań University of Life Sciences, Wojska Polskiego str.28, 60-627, Poznań, Poland, phone: +48618487483;

email:trogoz@up.poznan.pl simple nutrients. Through their metabolism they degrade wood tissues releasing hence many bound compounds, e.g. bound sterols (2).

During wood conversion and woodworking, to a lesser or greater extent large amounts of waste composed of fine wood dust particles are produced, which may be dispersed in the air causing contamination of the work place $(3,4)$. Wood dusts - both dispersed in the air inside a production plant and deposited - contain also the so-called biological agents of the work environment. This term refers to microand macroorganisms, as well as the structures and substances produced by these organisms, which have an adverse effect on the human organism and may cause numerous diseases. Common hazardous biological agents include e.g. microscopic fungi (Directive 2000/54/EC). This health hazard is mainly the result of the size of spores produced by microscopic fungi, ranging from around a dozen to several dozen micrometers. Due to their dimensions they may easily penetrate human airways and skin pores. To date, there are only few reports on sterol contents in wood dusts. Their presence in wood was confirmed and the concentration was determined (5-7). The greatest exposure of workers to wood dust contaminated with mycobiota and their toxic metabolites is recorded in the manufacture of wood furniture and in joinery workshops, mainly during manual and machine sanding. Due to the high risk of occupational diseases resulting from the exposure of employees to wood dust numerous safety measures have been implemented as part of good manufacturing practices (8). However, this is frequently 
insufficient to eliminate the hazards connected with the presence of moulds in the work environment (9). For this reason, in this study it was decided to analyse the contamination with mycobiota in wood dust at various work stations in a plant producing wooden furniture elements and other small wood products. The species origin of the analysed wood dust is closely related to the type of raw material used in that plant. In this case two wood species are processed. Contamination of the work environment involves three combinations of wood dust found there, i.e. pine wood dust, birch wood dust, and pine and birch wood dust, a mixture produced under technological process conditions. Microscopic fungi in dust can be analysed using the following methods: chemical for testing the concentrations of ergosterol (ERG) and adenosine 5 '-triphosphate (ATP), microbiological for determining e.g. colony-forming units (CFU), and genetic, such as ELISA tests (10). Among the above-mentioned methods, the analysis of ERG concentration is becoming increasingly the method of choice for testing various types of materials, not only biological. ERG is a good indicator of living and dead fungal contents in plant material (11-14).

Based on the ERG concentration and the profile of endogenous sterols found, the aim of this study was to assess the level of contamination with microscopic fungi in pine and birch wood dust resulting after the processing of wood of these two tree species. Most compounds found in wood dusts have already been thoroughly analysed, while the profile of sterols has been investigated only superficially. For this reason it was decided to study this problem in more detail by analysing sterol concentrations in wood dust using ultra performance liquid chromatography (UPLC).

\section{MATERIALS AND METHODS}

\section{Description of technologies in the wood processing plant}

Wood dust deposited on work surfaces of eight work stations was sampled at a plant manufacturing pine and birch wood products (Table 1). The technological process performed at this plant comprises both preliminary treatment and secondary woodworking. In the former stage, roundwood is converted (work station 1) and planks are

Table 1 Work stations, from which samples were collected

\begin{tabular}{|c|c|c|}
\hline No. & & Work station \\
\hline 1 & \multirow{5}{*}{$\begin{array}{c}\text { Primary } \\
\text { woodworking }\end{array}$} & Gangsaw \\
\hline 2 & & Multi-rip saw machine \\
\hline 3 & & Cross-cut saw \\
\hline 4 & & Planer \\
\hline 5 & & Optimizer saw \\
\hline 6 & \multirow{3}{*}{$\begin{array}{c}\text { Secondary } \\
\text { woodworking }\end{array}$} & Thickness planer \\
\hline 7 & & Dimension saw \\
\hline 8 & & Sanding machine \\
\hline
\end{tabular}

produced, from which smaller-sized assortments are derived using a multi-rip saw (work station 2) and a cross-cut saw (squared logs, battens) (work station 3 ). In this form pine wood is transferred to the kiln, while birch wood is dried in the form of planks prior to sawing. Dried wood is planed (work station 4) to provide smoothness and prepare wood material for further processing. The last operation at this stage of the process is to eliminate wood defects using an optimizer saw machine (work station 5). Produced shop lumber is sent to woodworking operations, where following surface smoothing during planing (work station 6) it is glued side to side (temperature $70^{\circ} \mathrm{C}$ ). After gluing, the panels are profiled by dimensioning (cross-cutting to length) (work station 7), profiling (four-sided planer), and tenoning. At the end of this stage of the technological process the products are sanded (work station 8) to smooth the surface before its finishing and lacquer refining.

\section{Dust sampling}

Table 1 presents a list of the work station surfaces from which samples were collected.

Samples of approx. $5 \mathrm{~g}$ were collected from working surfaces of each of the eight work stations using sterile spatulas as described by Rogoziński et al. (13). Samples were collected after the end of three shifts in three replications for each wood type: birch, pine and their mixture, when pine and birch wood was worked simultaneously. Thus a total of 72 wood dust samples were tested: eight pine wood dust samples, eight birch dust samples, and eight mixed birch and pine dusts.

\section{Chemical analysis}

\section{Chemicals and reagents}

Methanol, acetonitrile (Sigma-Aldrich, St. Louis, MO, USA) and pentane (Sigma-Aldrich, Steinheim, Germany) were HPLC grade. Hydrochloric acid and sodium hydroxide were purchased from POCH S.A. (Gliwice, Poland); deionised water was prepared using the Millipore Milli-Q system (Millipore, MA, USA). TMS (trimethylsilyl), BSTFA (N,O-bis(trimethylsilyl)trifluoroacetamide) and TMCS (trimethylchlorosilane) (Sigma-Aldrich, St. Louis, MO, USA) were used to prepare ether derivatives of sterols. The standards of desmosterol, cholesterol, lanosterol, stigmasterol, $\beta$-sitosterol, and ergosterol were purchased from Sigma-Aldrich (St. Louis, MO, USA).

\section{Sterol extraction}

Sterols were determined following microwave assisted basic hydrolysis. Samples of $100 \mathrm{mg}$ ground material were placed into $17-\mathrm{mL}$ culture tubes, suspended in $1 \mathrm{~mL}$ of methanol, treated with $0.1 \mathrm{~mL}$ of $2 \mathrm{M}$ aqueous $\mathrm{NaOH}$, and sealed tightly. Then the culture tubes were put into $250-\mathrm{mL}$ plastic bottles, sealed tightly, and placed inside a microwave 
oven (Whirpool model AVM 401/WH) operating at $2450 \mathrm{MHz}$ and $900 \mathrm{~W}$ maximum output. Samples were irradiated $(370 \mathrm{~W})$ for $20 \mathrm{~s}$, after c. $5 \mathrm{~min}$, for additional $20 \mathrm{~s}$ and extracted with pentane $(3 \times 4 \mathrm{~mL})$ to the culture tubes. The combined pentane extracts were evaporated to dryness under a gentle stream of high purity nitrogen using a RapidVap Evaporator (Labconco, Kansas, MO, USA). The extracts were stored at $-25{ }^{\circ} \mathrm{C}$ until analysis. Prior to analysis, samples were dissolved in $1 \mathrm{~mL}$ of methanol and filtered through $13-\mathrm{mm}$ syringe filters with $0.22 \mu \mathrm{m}$ pore diameter (Fluoropore Membrane Filters).

\section{UPLC analysis}

Quantitative analysis of the sterol content was performed using an Aquity H class UPLC system equipped with a Waters Acquity photodiode array (PDA) detector (Waters, USA). Chromatographic separation was performed on a Acquity UPLC ${ }^{\circledR}$ BEH C18 column $(100 \mathrm{~mm} \times 2.1 \mathrm{~mm}$, particle size $1.7 \mu \mathrm{m}$ ) (Waters, Ireland). The elution was carried out isocratically using the following mobile phase composition: A, acetonitrile $10 \%$; B, methanol $85 \%$; C, water $5 \%$, flow $0.5 \mathrm{~mL} \mathrm{~min}^{-1}$. The injection volume was 2 $\mu \mathrm{L}$.

Sterol concentrations were measured using an external standard at wavelengths $\lambda=210 \mathrm{~nm}$ (desmosterol, cholesterol, lanosterol, stigmasterol, $\beta$-sitosterol) and $\lambda=$ $282 \mathrm{~nm}$ (ergosterol). Compounds were identified based on the comparison between retention times of the examined peak and that of the standard and by adding a specific amount of the standard to the tested sample and repeated analyses. The limit of detection was $1 \mathrm{mg} \mathrm{kg}^{-1}$.

\section{Gas chromatography/mass spectrometry (GC/MS) analysis}

Qualitative analysis of sterols was carried out by GC/ MS. The extracts were dissolved in $1 \mathrm{~mL}$ of methanol. Sterols were analysed as TMS (trimethylsilyl) ether derivatives prepared by treatment of the sterols with $200 \mu \mathrm{L}$ of a $1: 1(\mathrm{v} / \mathrm{v})$ mixture of pyridine and BSTFA (N,Obis(trimethylsilyl)trifluoroacetamide) $+1 \%$ TMCS (trimethylchlorosilane) in a capped vial. The reaction mixture was heated to $60{ }^{\circ} \mathrm{C}$ for $30 \mathrm{~min}$. After cooling to room temperature, reaction mixture was injected into a gas chromatograph (GC). Gas chromatography was performed using a Varian 450-GC system (Varian Inc., Netherlands) equipped with a Varian 320-MS mass spectrometer detector (Varian Inc., Walnut Creek, CA, USA). The column used was HP-5MS, $0.25 \mathrm{~mm}$ i.d. $\times 30 \mathrm{~m} \times 0.25 \mu \mathrm{m}$ (Varian Inc., Netherlands) film thickness capillary column. The oven temperature was initially $200{ }^{\circ} \mathrm{C}$ for $1 \mathrm{~min}$. and then programmed from 200 to $290{ }^{\circ} \mathrm{C}$ at $15^{\circ} \mathrm{C} \mathrm{min}{ }^{-1}$. The final temperature was held for $15 \mathrm{~min}$. The injector temperature was $290^{\circ} \mathrm{C}$, while the transfer line temperature was $280^{\circ} \mathrm{C}$. Helium was used as a carrier gas at a flow rate of $0.7 \mathrm{~mL} \mathrm{~min}^{-1}$. The mass detector was used in the electron impact mode, with an electron energy of $70 \mathrm{eV}$. Detection was conducted in the full scan mode, from $\mathrm{m} / \mathrm{z} 40-500$ or in the single ion mode with the monitoring following ions per sterols: cholesterol - 329, 353, 458; desmosterol - 327, 351 , 441; ergosterol - 253, 337, 363; stigmasterol - 355, 394, 484; $\beta$-sitosterol - 396, 486; and lanosterol - 393, 483.

\section{Statistical analysis}

Results recorded in the course of the conducted chemical analyses were subjected to statistical analysis with the use of the STATISTICA ver. 8.0 (StatSoft USA) software. In order to compare the contents of individual metabolites in samples. Normality of distribution was tested by ANOVA. Tukey's multiple comparison procedure was used, with identical letters in rows or columns denoting a lack of differences at the significance level $\alpha=0.05$. Moreover, a stepwise linear discriminant analysis (SLDA) was performed in order to separate groups in the analysed populations. Additionally, the classification matrix and multivariate significance tests were applied.

\section{RESULTS}

Within this study, analyses were conducted on 72 samples of wood dusts deposited at various work stations at a wood processing plant. Sampled wood dusts were divided into three types: pine wood dust, birch wood dust, and pine-birch wood dust (a detailed description of samples is given in the Material and Methods). In the samples, the concentration of ERG, which is a chemical marker of contamination with mycobiota (Table 2), and the concentration of other sterols (Table 3) were determined. Based on the recorded ERG concentration, the greatest contamination of microscopic fungi was found in birch wood dust, $20.59 \mathrm{mg} \mathrm{kg}^{-1}$ d.m. (dry mass). Birch-pine wood dust was characterised by a significantly lower mean ERG concentration of $5.69 \mathrm{mg} \mathrm{kg}^{-1}$. The content of ERG in pine wood dust samples was the lowest, amounting to $2.48 \mathrm{mg} \mathrm{kg}^{-1}$. It did not differ significantly from the concentration of this metabolite in pine-birch wood dust samples.

An example UPLC chromatogram is given in Figure 1, presenting the analysed sterols in the sample. The sterol profile varied in the three tested wood dust types (Figure

Table 2 Concentration of ergosterol (ERG) determined by UPLC

\begin{tabular}{lc}
\hline Type of wood dust & ERG concentration $\left(\mathbf{m g ~ k g}^{-1}\right)$ \\
\hline Pine dust & $1.25-6.94$ \\
& $2.48^{\mathrm{a}} \pm 1.21$ \\
\hline Mixed pine and & $1.40-10.47$ \\
birch dust & $5.69^{\mathrm{a}} \pm 2.39$ \\
\hline \multirow{2}{*}{ Birch dust } & $1.75-44.40$ \\
& $20.59^{\mathrm{b}} \pm 10.38$ \\
\hline - identical letters in the column do not differ significantly at \\
$=0.05$, according to HSD Tukey test
\end{tabular}




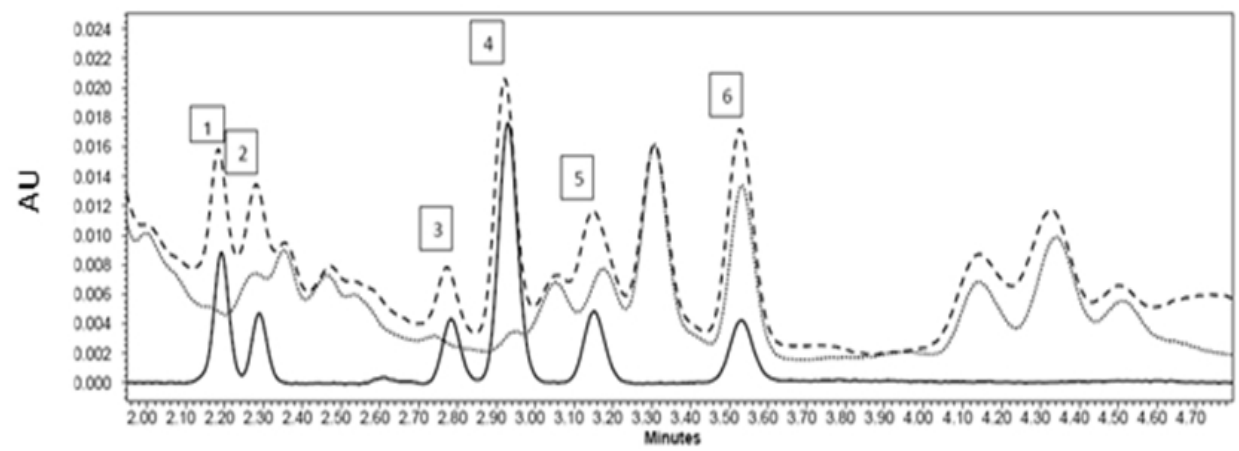

Figure 1 Chromatogram of sterol standards (black line) - desmosterol (1), ergosterol (2), cholesterol (3), lanosterol (4), stigmasterol (5), and $\beta$-sitosterol (6); sample no. 11 (dotted line) and sample no. 11 fortified with standards (dashed line)

2). The sample with the addition of standards and the obtained chromatogram was compared with the chromatogram of the standards. Among the investigated sterols, the highest concentration was recorded for stigmasterol and $\beta$-sitosterol for all analysed wood dust samples. Other sterols were recorded at lower concentrations ranging from approx. $1 \mathrm{mg} \mathrm{kg}^{-1}$ for pine dust to approx. $30 \mathrm{mg} \mathrm{kg}^{-1}$ for birch dust (Table 3). These data were compared both in terms of the qualitative composition using a GC/MS. Recorded results were analysed statistically showing significant differences between wood dust types for all the sterols. The highest sterol content was recorded in birch dust, while it was lower for mixed pine and birch dust and the lowest for pine dust. The greatest differences were found for stigmasterol. In birch dust, the concentration of this sterol was on average $175.98 \mathrm{mg} \mathrm{kg}^{-1}$, in mixed pine and birch dust its content was almost four-fold lower, whereas in pine dust it was over five-fold lower. In the case of $\beta$-sitosterol, no significant differences were recorded between its concentration in pine dust and in mixed pine and birch dust and its level was by almost $25 \%$ lower than in birch dust. Among other sterols, desmosterol had the lowest concentration for birch dust, amounting to approx. $30 \mathrm{mg} \mathrm{kg}^{-1}$ in other types of wood dusts, i.e. on average two-fold less. A similar trend was observed for cholesterol and lanosterol.

The discriminant analysis showed a complete separation of all three analysed wood dust types. The greatest discriminatory power was found for stigmasterol, desmosterol, and ergosterol (Figure 3). The correlation matrices presented in Table 4 showed a significant correlation between ERG as an indicator of contamination with mycobiota and endogenous sterols in wood. The lowest correlation levels were observed for pine dust, while it was higher for mixed pine and birch dust and the highest for birch dust. Moreover, the largest number of significant correlations was found for pine dust. With an increase in significance, the number of significant correlations decreased for pine dust, mixed pine, and birch dust and birch dust.

\section{DISCUSSION}

The level of contamination with microscopic fungi is connected with the presence of antifungal and antioxidant compounds in wood. Several such compounds were identified in pine wood. Monoterpene hydrocarbons are predominant here: $\alpha$-pyrene, 3 -carene, $\beta$-pinene, limonene, camphene, and $\beta$-phellandrene (16). In the case of birch, fewer antimicrobial compounds were identified, of which the most important were 14-hydroxy- $\beta$-caryophyllene, $\alpha$-betulenol, 14 -acetoxy- $\beta$-caryophyllene, and 14-hydroxy-4-5, dihydroxy- $\beta$-caryophyllene (17). Several of these compounds exhibit antifungal properties against Candida glabrata (18), while their antibacterial effects were

Table 3 The range and the mean of concentrations $\left(\mathrm{mg} \mathrm{kg}^{-1}\right)$ determined by UPLC for analysed wood endogenous sterols contained in three groups of wood dusts

\begin{tabular}{|c|c|c|c|c|c|}
\hline Type of wood dust & & & erols (mg kg- & & \\
\hline $\begin{array}{l}\text { Range } \\
\text { Mean } \pm \text { SD }\end{array}$ & Desmosterol & Cholesterol & Lanosterol & Stigmasterol & $\beta$-sitosterol \\
\hline Pine dust & $\begin{array}{c}1.22-23.80 \\
10.00^{\mathrm{a}} \pm 7.11\end{array}$ & $\begin{array}{l}1.11-10.80 \\
4.08^{\mathrm{a}} \pm 3.21\end{array}$ & $\begin{array}{c}1.26-3.8 \\
1.76^{\mathrm{a}} \pm 0.21\end{array}$ & $\begin{array}{c}24.8-42.42 \\
35.62^{\mathrm{a}} \pm 7.37\end{array}$ & $\begin{array}{l}163.80-312.40 \\
227.99^{\mathrm{a}} \pm 33.18\end{array}$ \\
\hline $\begin{array}{l}\text { Mixed pine and } \\
\text { birch dust }\end{array}$ & $\begin{array}{c}11.12-43.70 \\
18.04^{b} \pm 12.64\end{array}$ & $\begin{array}{c}1.22-22.08 \\
10.24^{\mathrm{a}} \pm 4.48\end{array}$ & $\begin{array}{c}1.04-9.40 \\
3.55^{\mathrm{a}} \pm 4.48\end{array}$ & $\begin{array}{c}10.36-54.74 \\
48.05^{\mathrm{b}} \pm 20.08\end{array}$ & $\begin{array}{c}94.33-371.80 \\
232.17^{\mathrm{a}} \pm 126.03\end{array}$ \\
\hline Birch dust & $\begin{array}{c}14.37-52.37 \\
29.57^{c} \pm 10.45\end{array}$ & $\begin{array}{l}10.58-29.44 \\
20.36^{b} \pm 6.12\end{array}$ & $\begin{array}{l}5.38-10.55 \\
8.05^{\mathrm{b}} \pm 2.08\end{array}$ & $\begin{array}{c}86.32-246.37 \\
175.98^{\circ} \pm 25.34\end{array}$ & $\begin{array}{l}284.24-378.55 \\
306.34^{b} \pm 72.38\end{array}$ \\
\hline
\end{tabular}

$\overline{a, b, c}$ - identical letters in the column do not differ significantly at $p=0.05$, according to HSD Tukey test 

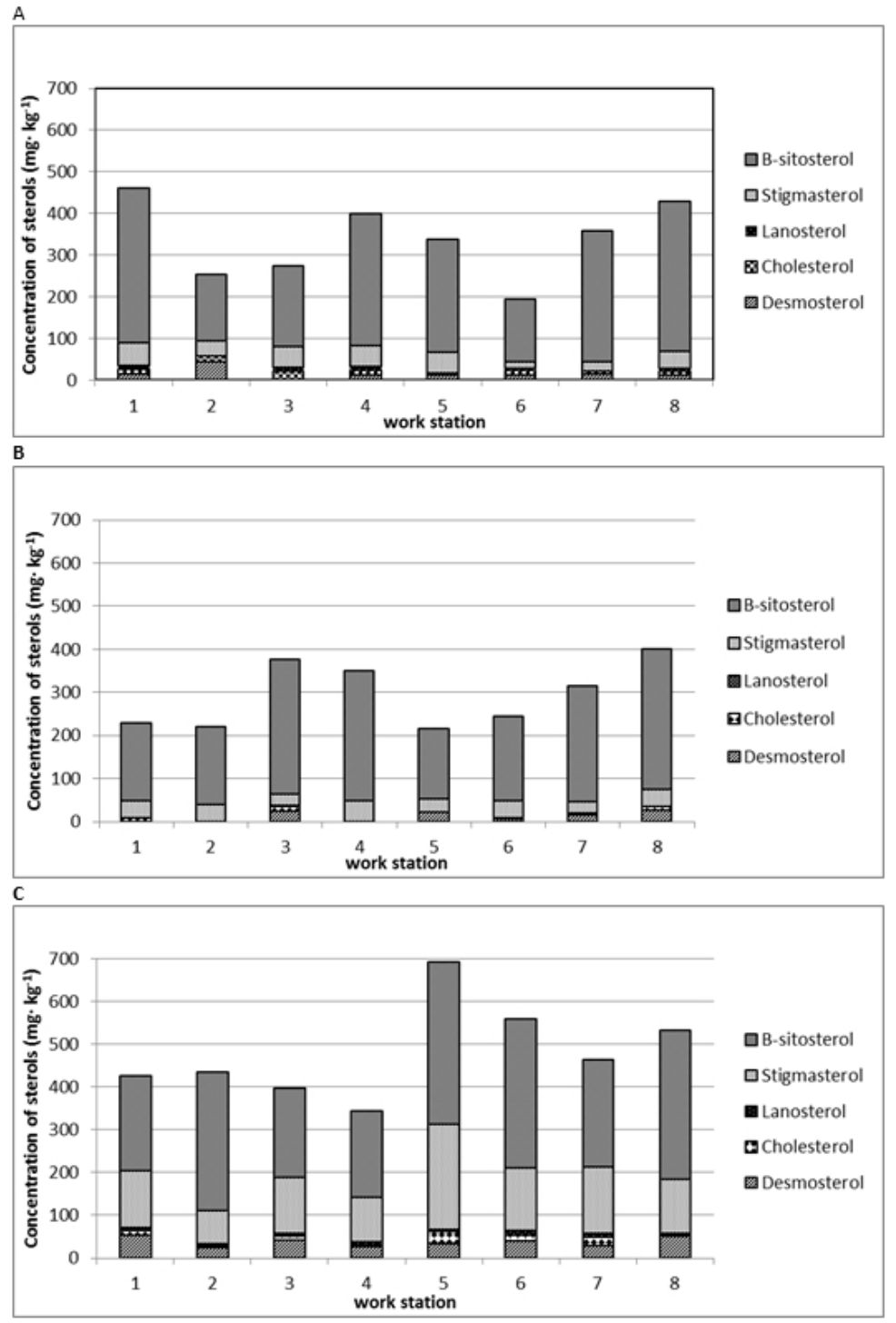

Figure 2 The profile of sterols $\left(m g \mathrm{~kg}^{-1}\right)$ in pine dust (A), mixed pine and birch dust (B), and birch dust (C)

those primarily observed (19). Based on this study, it was found that the content of ergosterol and thus the level of contamination with microscopic fungi in the analysed wood dust is closely related with the species of wood in wood dust. Birch wood is exposed to the greatest risk of contamination with mycobiota (15), as confirmed by this study. This is probably connected with the limited amount of components exhibiting antifungal properties in comparison with pine wood, which contained much greater levels of such compounds. A mixture of wood dusts composed of both wood species (mixed pine and birch dust) contained an average amount of antifungal components, thus the recorded ERG level in the dust mixture was greater than in pine dust, but it was lower than in birch dust. As a result of the effect of microscopic fungi, xylem is degraded, resulting in the secretion of cell wall components. The more porous or mechanically damaged the wood surface, the easier the penetration of mycelium. In the case of wood dust produced on the manufacturing lines and deposited on work surfaces, it is exposed to secondary contamination with mycobiota. This is connected with the conditions found in the wood industry plant, as well as the enhanced nutrient bioavailability for the pathogen as a result of irreversibly damaged macro-and microscopic structure of wood worked using cutting tools. Literature on the subject contains practically no data on the ERG content in dust produced during wood conversion and processing. It only contains information concerning the concentration of this metabolite in dust sampled in housing facilities. Pasanen et al. (20) reported an ERG concentration in such samples within the range of $6 \mathrm{mg} \mathrm{kg}^{-1}$ to $45 \mathrm{mg} \mathrm{kg}^{-1}$. Higher ERG concentrations were reported in similar samples by Saraf et al. (21), who provided ERG concentrations ranging from $20 \mathrm{mg} \mathrm{kg}^{-1}$ to $165 \mathrm{mg} \mathrm{kg}^{-1}$. Szwajkowska-Michałek et al. (17) analysed dusts coming from laboratories conducting cereal analyses. They found ERG concentrations in all tested samples to range from $0.48 \mathrm{mg} \mathrm{kg}^{-1}$ to $212.36 \mathrm{mg} \mathrm{kg}^{-1}$. Data concerning ERG contents in dusts do not specify a concentration 
Table 4 Matrix of correlation for sterol profiles in pine dust (A), mixed pine and birch dust (B), birch dust (C)

\begin{tabular}{|c|c|c|c|c|c|c|}
\hline A & Desmosterol & Cholesterol & Lanosterol & Stigmasterol & $\beta$-sitosterol & Ergosterol \\
\hline Desmosterol & 1 & & & & & \\
\hline Cholesterol & 0.4406 & 1 & & & & \\
\hline Lanosterol & $0.7061 *$ & $0.7264^{*}$ & 1 & & & \\
\hline Stigmasterol & 0.3529 & 0.3369 & 0.1264 & 1 & & \\
\hline$\beta$-sitosterol & 0.6301 & 0.5595 & 0.5375 & $0.8730^{*}$ & 1 & \\
\hline Ergosterol & $0.7287^{*}$ & 0.0177 & 0.4199 & $0.7655^{*}$ & $0.8397^{*}$ & 1 \\
\hline B & Desmosterol & Cholesterol & Lanosterol & Stigmasterol & $\beta$-sitosterol & Ergosterol \\
\hline Desmosterol & 1 & & & & & \\
\hline Cholesterol & 0.3634 & 1 & & & & \\
\hline Lanosterol & -0.0341 & 0.3760 & 1 & & & \\
\hline Stigmasterol & 0.4061 & 0.5048 & $0.7189^{*}$ & 1 & & \\
\hline$\beta$-sitosterol & 0.3930 & 0.3045 & 0.6168 & $0.8951^{*}$ & 1 & \\
\hline Ergosterol & $0.9535 * *$ & 0.0261 & 0.5743 & $0.8508^{*}$ & $0.8703^{*}$ & 1 \\
\hline $\mathbf{C}$ & Desmosterol & Cholesterol & Lanosterol & Stigmasterol & $\beta$-sitosterol & Ergosterol \\
\hline Desmosterol & 1 & & & & & \\
\hline Cholesterol & 0.3731 & 1 & & & & \\
\hline Lanosterol & $0.7076^{*}$ & -0.1720 & 1 & & & \\
\hline Stigmasterol & 0.5005 & $0.8252 *$ & 0.1866 & 1 & & \\
\hline$\beta$-sitosterol & -0.2369 & 0.2918 & 0.0156 & 0.1921 & 1 & \\
\hline Ergosterol & $0.9598 * *$ & 0.6065 & $0.8699 *$ & $0.9849 * *$ & $0.9795 * *$ & 1 \\
\hline
\end{tabular}

recorded in dust which could constitute a health hazard for people exposed to them. The only information on a safe concentration limit for this metabolite was provided by Maupetit et al. (22), who established the ERG concentration range from 1 to $9 \mathrm{mg} \mathrm{kg}^{-1}$ as a safe limit for grain for human consumption. In turn, Schnürer and Jonsson (23) for this same plant material adopted $3 \mathrm{mg} \mathrm{kg}^{-1}$ as a safe limit. In contrast, Pasanen et al. (20) reported that in a pure fungal culture (ERG concentrations vary slightly depending on the type and species of fungi), the mean ERG concentration is approx. $1850 \mathrm{mg} \mathrm{kg}^{-1}$. In view of these data, it may be concluded that ERG concentration in wood dust samples tested in this study is low in pine dusts, while it is medium for the mixed pine and birch dust. The level of birch dust contamination with mycobiota was high, which may indicate a significant hazard related both to mycelium filaments, fungal spores, and the presence of mycotoxins. The concentration of endogenous sterols released from wood is connected with the level of contamination with mycobiota. Speranza et al. (24) showed that the total sterol content in wood changed as a result of bacterial action. Sterol content in wood is also to a certain degree connected with wood species. Cheikh-Rouhou et al. (25) showed the percentage share of individual sterols in total sterols of pine wood. Stigmasterol was the main sterol (at approx. $20 \%$ ), with a lesser share of $\beta$-sitosterol (approx. $9 \%$ ). These researchers also detected a slight share $(1 \%)$ of cholesterol.
Sterol content also varied in individual wood layers (7). Villaverde et al. (6) analysed sterol concentrations in wood of white oak, black oak, and in bay laurel. They recorded a high concentration of $\beta$-sitosterol in bay laurel, amounting to $1650 \mu \mathrm{g} \mathrm{g}^{-1}$, while in white oak and black oak it was on average over three-fold lower, at $701 \mu \mathrm{g} \mathrm{g}^{-1}$ and $592 \mu \mathrm{g} \mathrm{g}^{-1}$. The role of sterols in plant tissues during pathogen infection has not been sufficiently explained. Some researchers suggest that $\alpha$ - and $\beta$-sitosterol may block gene expression in certain pathogens, e.g. Phytophthora ramo rum. Cholesterol is the primary component of leaf surface lipids in trees (5), while $\beta$-sitosterol is the building block in tissues. Thus, the role of these sterols in pathogenesis is connected with the site of the pathogen's attack. Upon wood infection or as is the case of wood dusts analysed in this study, tissue sterols play a significant role. Wood dusts are dead tissues and for this reason the role of sterols may not be discussed in the context of defence mechanisms in plants.

During wood decay, microscopic fungi degrade reserve substances. Major substances released during degradation include phytosterols contained in cell membranes and cell walls. Susceptibility of plant organisms to microbial infections is connected with the stability and impermeability of cell membranes. Sterols are essential components of xylem cell walls and membranes (15). For this reason, within this study the contents of selected major sterols were analysed in wood dust samples (Table 3). 


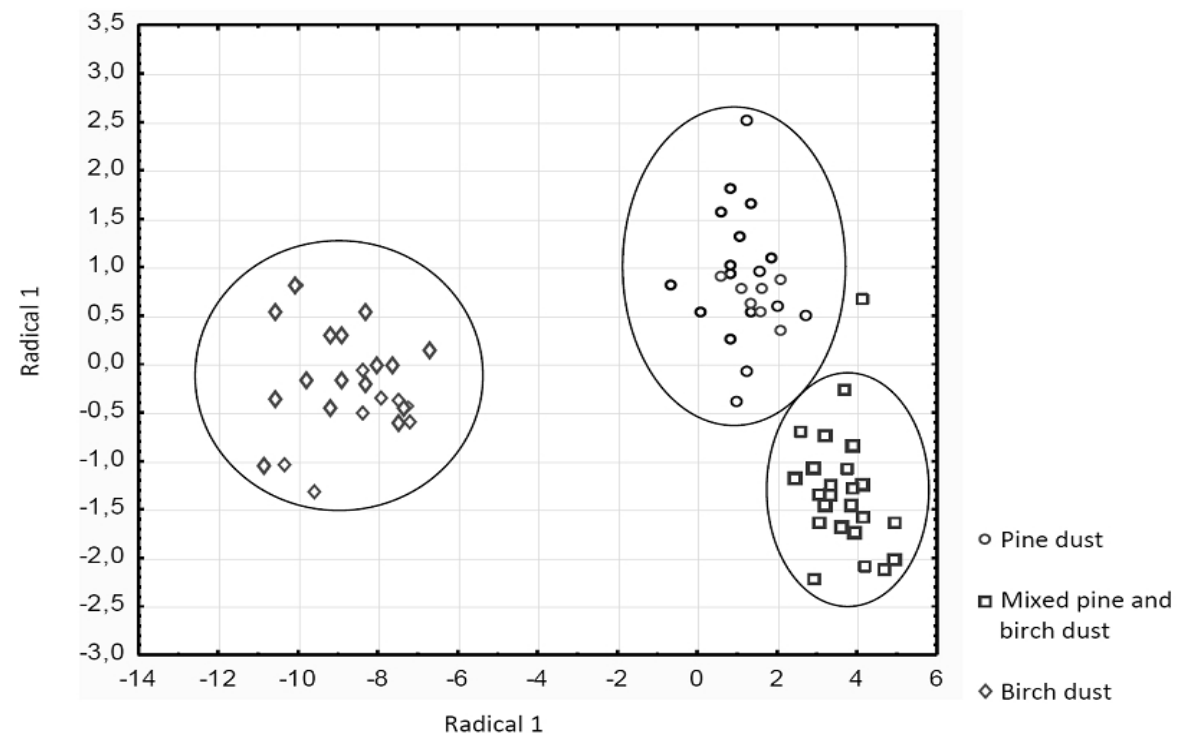

Figure 3 Discriminant analysis of three analysed wood types based on the sterol profile and ergosterol concentration. The greatest discriminatory power was found for the following compounds: stigmasterol (Lambda Wilks: 0.3174, $F_{\text {removal }}: 43.0244$ ), desmosterol (Lambda Wilks: 0.0803, F : 8.6458), and ergosterol (Lambda Wilks: 0.1306, F, 15.9403)

The tests conducted in this study indicate a significant problem connected with secondary infection of wood dusts deposited during storage on work surfaces at wood industry plants. To date, searching for a cause and effect relationship and dependencies between the level of contamination with mycobiota and the concentration of endogenous sterols in wood has not been a research problem discussed in literature on the subject. The analyses made in this study showed significant differences between the types of wood dusts in terms of their concentrations of all sterols. Analysis of correlations between the investigated sterols showed a significant dependence between ERG as an indicator of the level of contamination with mycobiota and endogenous sterols in wood. Interesting results obtained and dependencies observed based on the statistical analyses concerning the various types of wood dusts indicate that the problem of contamination with mycobiota is extensive and complex. It is crucial for health safety of employees at wood industry plants to continue such studies.

\section{CONCLUSIONS}

In wood dusts sampled at eight work stations in a plant processing pine and birch wood five endogenous sterols of wood were detected. Their concentrations were higher in birch dust, while it was only significantly higher in pine dust. The content of ERG, which is a chemical marker of contamination with mycobiota, was determined in wood dusts. The concentration of this fungal metabolite was also significantly higher in birch dust. Based on the results of chemical analyses, it was thus found that the concentrations of the analysed sterols varied depending on the type of wood from which wood dust originated and on the level of contamination with mycobiota. The level of ERG content pointing to the mycobiota presence recorded in birch dust indicates significant contamination with such microorganisms in wood dust deposited on work surfaces. It is crucial information from the point of view of health safety of the employees working in wood industry plants. This study contributes to the identification of the threat of fungal diseases in such plants. However, the dust collected from working surfaces was primarily dispersed in the air (could contain the inhalable fraction), then settled during a working shift. The dust can be of course redispersed under the impact of different factors (operation of machines, transport devices, movement of employers and materials, air circulation etc.). Studies on endogenous sterols in wood in this context constitute the basis for further research aiming at the determination of their involvement in metabolism of mycobiota during colonisation of wood and wood waste.

\section{REFERENCES}

1. Higuchi T, editor. Biosynthesis and Biodegradation of Wood Components. Orlando (FL): Academic Press Inc.; 1985.

2. Fengel D, Wegener G. Wood: Chemistry, Ultrastructure, Reactions. New York (NY): Walter de Gruyter; 1983.

3. Palmqvist J, Gustafsson SI. Emission of dust in planing and milling of wood. Holz Roh Werkst 1999;57:164-70. doi: 10.1007/s001070050035

4. Očkajová A, Kučerka M, Krišták L, Ružiak I, Gaff M. Efficiency of sanding belts for beech and oak sanding. Bioresources 2016;11:5242-54. doi: 10.15376/ biores.11.2.5242-5254

5. Noda M, Tanaka M, Seto Y, Aiba T, Oku C. Occurrence of cholesterol as a major sterol component in leaf surface lipids. Lipids 1988;23:439-44. doi: 10.1007/BF02535517

6. Villaverde JJ, Domingues RMA, Freire CSR, Silvestre AJD, Neto CP, Ligero P, Vega A. Miscanthus x giganteus 
extractives: a source of valuable phenolic compounds and sterols. J Agric Food Chem 2009;57:3626-31. doi: 10.1021/ jf900071t

7. Stong RA, Kolodny E, Kelsey RG, González-Hernández MP, Vivanco JM, Manter DK. Effect of plant sterols and tannins on Phytophthora ramorum growth and sporulation. J Chem Ecol 2013;39:733-43. doi: 10.1007/s10886-013-0295-y

8. Jacobsen G. Schaumburg I. Sigsgaard T. Schlünssen V. Nonmalignant respiratory diseases and occupational exposure to wood dust. Part II. Dry wood industry. Ann Agric Environ Med 2010;17:29-44. PMID: 20684478

9. Čavlović AO, Beljo Lučić R, Jug M, Radmanović K, Bešlić I. Side-by-side determination of workers' exposure to wood dust with IOM and openfaced samplers. Arh Hig Rada Toksikol 2013;64:379-84. doi: 10.2478/10004-1254-642013-2316

10. Cumagun CJR, Rabenstein F, Miedaner T. Genetic variation and covariation for aggressiveness, deoxynivalenol production and fungal colonization among progeny of Giberella zeae in wheat. Plant Pathology 2004;53, 446-453.

11. Perkowski J, Buśko M, Stuper K, Kostecki M, Matysiak A, Szwajkowska-Michałek L. Concentration of ergosterol in small - grained naturally contaminated and inoculated cereals. Biologia 2008;63:542-7. doi: 10.2478/s11756-0080083-2

12. Szwajkowska-Michałek L, Stuper K, Łakomy P, Matysiak A, Perkowski J. Contents of microscopic fungi in dusts coming from cereal analysis laboratories. Ann Agric Environ Med 2010;17:101-6. PMID: 20684486

13. Rogoziński T, Szwajkowska-Michałek L, Dolny S, Andrzejak A, Perkowski J. The evaluation of microfungal contamination of dust created during woodworking in furniture factories. Med Pr 2014;65:705-13. PMID: 25902688

14. Dillon KH, Boling KD, Miller DJ. Comparison of detection methods for Aspergillus fumigatus in environmental air samples in an occupational environment. J Occup Environ Hyg 2007;4:509-13. doi: 10.1080/15459620701404013

15. Piispanen R, Saranpää P. Seasonal and within-stem variations of neutral lipids in silver birch (Betula pendula) wood. Tree Physiol 2004;24:991-9. doi: 10.1093/treephys/24.9.991

16. Edman K, Löfstedt H, Berg P, Eriksson K, Axelsson S, Bryngelsson I, Fedeli C. Exposure assessment to $\alpha$ - and $\beta$-Pinene, $\Delta 3$-Carene and wood dust in industrial production of wood pellets. Ann Occup Hyg 2003;47:219-26. doi: 10.1093/annhyg/meg024

17. Thompson BM, Grebenok RJ, Behmer ST, Gruner DS. Microbial symbionts shape the sterol profile of the xylemfeeding woodwasp, Sirex noctilio. J Chem Ecol 2013;39:12939. doi: 10.1007/s10886-012-0222-7

18. Gutiérrez A, del Río JC, Martínez MJ, Martínez AT. Fungal degradation of lipophilic extractives in Eucalyptus globulus wood. Appl Environ Microbiol 1999;65:1367-71. PMCID: PMC91193

19. Laakso P. Analysis of sterols from various food matrices. Eur J Lipid Sci Technol 2005;107:402-10. doi: 10.1002/ ejlt.200501134

20. Pasanen AL, Yli-Pietilä K, Pasanen P, Kalliokoski P, Tarhanen J. Ergosterol content in various fungal species and biocontaminated building materials. Appl Environ Microbiol 1999;65:138-42. PMCID: PMC90994

21. Saraf A, Larsson L, Burge H, Milton D. Quantification of ergosterol and 3-hydroxy fatty acids in settled house dust by gas chromatography-mass spectrometry: Comparison with fungal culture and determination of endotoxin by a Limulus amebocyte lysate assay. Appl Environ Microbiol 1997;63:2554-9. PMCID: PMC168553

22. Maupetit P, Gatel F, Cahagnier B, Botorel G, Charlier M, Collet B, Dauvillier P, Laffiteau J, Roux G. Quantitative estimation of fungal infestation of feedstuffs by determining ergosterol content. In: Clinquart A, Dufrasne I, Mayombo AP, Van Eenaeme C, Istasse L, editors. Proceedings of the $44^{\text {th }}$ Annual Meeting of the EAAP; 16-19 August 1993; Aarhus, Denmark. Abstracts

23. Schnürer J, Jonsson A. Ergosterol levels and mould colony forming units in Swedish grain of food and feed grade. Acta Agric Scand B 1992;42:240-5. doi: 10.1080/09064719209410219

24. Speranza M, Gutiérrez A, del Río JC, Bettucci L, Martínez AT, Martínez MJ. Sterols and lignin in Eucalyptus globulus Labill. wood: Spatial distribution and fungal removal as revealed by microscopy and chemical analyses. Holzforschung 2009;63:362-70. doi: 10.1515/HF.2009.041

25. Cheikh-Rouhou S, Besbes S, Lognay G, Blecker C, Deroanne C, Attia H. Sterol composition of black cumin (Nigella sativa L.) and Aleppo pine (Pinus halepensis Mill.) seed oils. J Food Comp Anal 2008;21:162-8. doi: 10.1016/j.jfca.2007.09.001

\section{Kontaminacija borove i brezine piljevine mikroskopskim gljivicama i određivanje njezina sadržaja sterola}

Piljevina je nedvojbeno najveća opasnost za zdravlje radnika u drvnoj industriji, a njezin je sastav povezan s vrstom drva, ali i s uvjetima radnoga mjesta. U ovom su radu ispitivani uzorci piljevine uzeti na raznim lokacijama unutar pogona za preradu borove i brezove drvne građe te je tekućinskom kromatografijom ultravisoke djelotvornosti (UPLC) mjeren stupanj kontaminacije gljivicama određivanjem koncentracije ergosterola (ERG). Drugi cilj ispitivanja bio je procijeniti utjecaj kontaminacije mikroskopskim gljivicama na sadržaj sterola u piljevini. UPLC metodom analizirano je pet sterola: dezmosterol, kolesterol, lanosterol, stigmasterola i $\beta$-sitosterol, a njihova prisutnost potvrđena je metodom plinske kromatografije uz detekciju spektrometrom masa (GC/MS). Rezultati kemijskih analiza pokazali su najvišu razinu gljivične kontaminacije u piljevini nastaloj obradom brezovine. Također smo uočili različite sadržaje pojedinačnih sterola, ovisno o vrsti piljevine. Njihova najviša koncentracija utvrđena je u brezovoj piljevini. Diskriminantna analiza, koja je obuhvatila sve ispitivane spojeve kao prediktore, pokazala je potpunu separaciju svih ispitanih tipova drvne piljevine. Najveća diskriminativna moć utvrđena je za stigmasterol, dezmosterol i ergosterol. 